\title{
Improving Learning Outcomes About the Human Circulatory System Through a Scientific Approach to Class V Students of SDN Arjosari
}

\section{Helmi Cahyono}

SDN Arjosari

kriwilgirang@gmail.com

\section{Article History}

accepted 14/11/2020

\begin{abstract}
The purpose of this study was to determine the extent to which student learning outcomes improved and to determine the extent to which the scientific approach was applied in learning about the human blood circulation system in class V SDN Arjosari, Adimulyo District, Kebumen Regency. The research conducted was a Classroom Action Research (CAR) in three cycles, with each cycle consisting of one meeting. The stages of each cycle are planning, implementing, observing and reflecting. Each meeting conducted a formative test to determine student learning outcomes. The first cycle was $22 \%$, the second cycle increased $67 \%$ to $89 \%$ and the third cycle increased $11 \%$ to $100 \%$. These results indicate that the scientific approach can improve student learning outcomes, especially Class V science muple at SDN Arjosari.
\end{abstract}

Keywords: Learning outcomes, scientific approach, science

\begin{abstract}
Abstrak
Tujuan penelitian ini adalah untuk mengetahui sejauh mana peningkatan hasil belajar siswa dan untuk mengetahui sejauh mana penerapan pendekatan saintifik dalam pembelajaran tentang sistem peredaran darah manusia di kelas V SDN Arjosari, Kecamatan Adimulyo, Kabupaten Kebumen. Penelitian yang dilakukan adalah Penelitian Tindakan Kelas (PTK) sebanyak tiga siklus, dengan setiap siklusnya terdiri dari satu pertemuan. Tahapan setiap siklusnya adalah perencanaan, pelaksanaan, observasi dan refleksi. Setiap pertemuan dilakukan tes formatif untuk mengetahui hasil belajar siswa. Siklus I sebesar $22 \%$, pada siklus II meningkat sebesar $67 \%$ menjadi $89 \%$ dan pada siklus III meningkat sebesar $11 \%$ menjadi $100 \%$. Hasil ini menunjukan bahwa pendekatan saintifik dapat meningkatkan hasil belajar peserta didik khususnya mupel IPA Kelas V di SDN Arjosari.
\end{abstract}

Kata kunci: hasil belajar, pendekatan saintifik, IPA

Social, Humanities, and Education Studies (SHEs): Conference Series https://jurnal.uns.ac.id/shes

p-ISSN 2620-9284

e-ISSN 2620-9292 


\section{PENDAHULUAN}

Irham (2014) menjelaskan bahwa kesulitan belajar merupakan sebuah permasalahan yang menyebabkan seseorang tidak dapat mengikuti proses pembelajaran dengan baik seperti siswa lain pada umumnya, yang disebabkan oleh faktor-faktor tertentu sehingga siswa terhambat atau bahkan tidak dapat mencapai tujuannya. Lebih lanjut Mulyono (2012: 8) menyatakan kesulitan belajar dapat terjadi karena faktor internal dan eksternal, oleh karena itu kegiatan belajar tidak selalu berjalan lancar. Pelaksanaan sistem pembelajaran jarak jauh yang telah dilaksanakan selama pandemi dinilai masih belum berjalan secara optimal di Sekolah Dasar Negeri Arjosari utamanya kelas V. Ada beberapa hal yang dinilai menjadi kendala, terutama mengenai akses internet. Hal tersebut terjadi karena lokasi Desa Arjosari sendiri juga jauh dari pusat kota sehingga akses internet tidak mampu digunakan secara maksimal. Kemudian, masalah kemampuan orangtua dalam mendampingi anak-anak di rumah juga masih kurang karena banyak orang tua siswa yang belum mengerti tentang sistem pendidikan saat ini. Permasalahan yang muncul selama belajar dari rumah di era Covid-19 ini perlu perhatian dari berbagai pihak agar dapat diatasi sehingga anakanak mendapatkan pendidikan secara utuh.

Dengan demikian, hasil penelitian dapat dijadikan pertimbangan bagi guru untuk memilih media dan pendekatan pembelajaran yang dianggap mampu menunjang proses pembelajaran di kelas dan dianggap paling efektif dan efisien sesuai kompetensi yang akan dicapai dengan tetap mengikuti perkembangan zaman. Segala masukan dan saran dari berbagai pihak menjadi sebuah kumpulan saran membangun bagi penulis sehingga penulis harus mencari sebuah pendekatan pembelajaran dengan mempertimbangkan saran dan masukan tersebut sekaligus juga dengan mempertimbangkan segala sarana dan prasarana yang dimiliki oleh sekolah. Menurut Yoga Prasetya (2016) melalui pendekatan saintifik menunjukkan analisis tes siswa setiap siklus menunjukan bahwa hasil belajar siswa mengalami peningkatan pada tiap siklusnya hingga mengalami peningkatan dengan ketuntasan belajar klasikal 87,88\%.

\section{METODE}

Penelitian ini adalah penelitian tindakan kelas (Classroom Action Research) dengan menerapkan pendekatan saintifik. Menurut Karar dan Yenice (2012), pendekatan saintifik adalah proses pembelajaran yang dirancang sedemikian rupa agar pembelajar secara aktif mengonstruk konsep, hukum atau prinsip melalui tahapan-tahapan mengamati (untuk mengidentifikasi atau menemukan masalah), merumuskan masalah, merumuskan hipotesis, mengumpulkan data dengan berbagai teknik, menganalisis data, menarik kesimpulan, dan mengomunikasikan konsep.

Analisis penelitian ini adalah analisis deskriptif kuantitafif kualitatif dimana dalam penelitian ini selain penyajian hasil berupa data maupun angka peneliti juga menentukan bagaimana cara pengolahan hasil penelitian yakni dengan membuat analisisnya dengan menerapkan pendekatan saintifik. Penelitian ini dilaksanakan pada peserta didik kelas V SD Negeri Arjosari Tahun Pelajaran 2020/2021 selama tiga siklus secara luring dengan satu pertemuan disetiap siklusnya. Siklus I dilaksanakan pada tanggal 2 November 2020. Siklus II dilaksanakan pada tanggal 9 November 2020. Siklus III dilaksanakan pada tanggal 20 November 2020. Teknik pengumpulan data yang dilakukan dengan observasi dan tes. Hasil belajar siswa diukur melalui tes formatif. Lembar observasi terdiri dari 3 yaitu observasi siswa, observasi guru, dan observasi RPP.

HASIL DAN PEMBAHASAN

Hasil dari siklus I merupakan konsep awal sebuah perbaikan pembelajaran dari hasil evaluasi pra siklus. Berikut ini adalah tabel yang dapat menggambarkan 
perkembangan nilai tes formatif dari pra siklus ke siklus 1 penelitian tindakan kelas yang telah dilaksanakan oleh penulis.

Tabel 1.Rekapitulasi hasil tes formatif siklus I

\begin{tabular}{clccccc}
\hline \multirow{2}{*}{ No } & Nama & Pra & \multicolumn{4}{c}{ Siklus 1 } \\
& Siswa & siklus & Nilai & MK & BMK & Ket. \\
\hline 1 & AZ & 47 & 60 & $\checkmark$ & BT \\
2 & ANF & 60 & 73 & $\checkmark$ & BT \\
3 & DTs & 53 & 73 & $\checkmark$ & BT \\
4 & HF & 47 & 60 & $\checkmark$ & BT \\
5 & HK & 47 & 53 & $\checkmark$ & BT \\
6 & KS & 20 & 33 & $\checkmark$ & BT \\
7 & NA & 60 & 80 & $\checkmark$ & T \\
8 & NR & 67 & 80 & $\checkmark$ & T \\
9 & TWR & 47 & 53 & $\checkmark$ & BT \\
Nilai rata-rata & 49,8 & 62,8 & & \\
MK (Mengalami Kenaikan), BMK (Belum Mengalami Kenaikan) \\
BT (Belum Tuntas KKM), T (Tuntas KKM)
\end{tabular}

Hasil siklus I dijabarkan sebagai berikut : mengalami kenaikan hasil belajar siswa mencapai $100 \%$ dari pra siklus ke siklus I, walaupun seluruh siswa mengalami kenaikan nilai hasil belajar tes formatif, namun masih ada 7 siswa yang belum tuntas nilai KKM yang ditetapkan yakni nilai 75, terdapat 2 siswa yang mengalami kenaikan nilai sekaligus tuntas nilai KKM, persentase siswa yang tuntas KKM adalah $22 \%$ dalam siklus I.

Berdasarkan refleksi pada siklus I maka diputuskan untuk melanjutkan ke siklus II dikarenakan belum mencapai ketuntasan klasikal yang diharapkan. Pada siklus II penggunaan alat peraga konkrit menjadi perbedaan dibanding siklus I. Berikut ini adalah hasil belajar peserta didik pada siklus II yang bisa dilihat pada tabel berikut.

Tabel 2.Rekapitulasi hasil tes formatif siklus II

\begin{tabular}{|c|c|c|c|c|c|c|}
\hline \multirow{2}{*}{ No } & \multirow{2}{*}{ Nama } & \multirow{2}{*}{ Siklus 1} & \multicolumn{4}{|c|}{ Siklus 2} \\
\hline & & & Nilai & MK & BMK & Ket. \\
\hline 1 & AZ & 60 & 80 & $\checkmark$ & & $\mathrm{T}$ \\
\hline 2 & ANF & 73 & 80 & $\checkmark$ & & $\mathrm{T}$ \\
\hline 3 & DTs & 73 & 87 & $\checkmark$ & & $\mathrm{T}$ \\
\hline 4 & $\mathrm{HF}$ & 60 & 93 & $\checkmark$ & & $\mathrm{T}$ \\
\hline 5 & HK & 53 & 93 & $\checkmark$ & & $\mathrm{T}$ \\
\hline 6 & $\mathrm{KS}$ & 33 & 67 & $\checkmark$ & & BT \\
\hline 7 & NA & 80 & 100 & $\checkmark$ & & $\mathrm{T}$ \\
\hline 8 & NR & 80 & 93 & $\checkmark$ & & $\mathrm{T}$ \\
\hline 9 & TWR & 53 & 80 & $\checkmark$ & & $\mathrm{T}$ \\
\hline \multicolumn{2}{|c|}{ Nilai rata-rata } & 62,8 & 85,9 & & & \\
\hline
\end{tabular}

MK (Mengalami Kenaikan), BMK (Belum Mengalami Kenaikan)

BT (Belum Tuntas KKM), T (Tuntas KKM)

Hasil siklus II dapat dijabarkan sebagai berikut : mengalami kenaikan hasil belajar siswa mencapai $100 \%$ dari siklus I, walaupun seluruh siswa mengalami kenaikan nilai hasil belajar tes formatif, namun masih ada 1 siswa yang belum tuntas nilai KKM yang ditetapkan yakni nilai 75 , Persentase siswa yang tuntas KKM adalah $89 \%$ dalam siklus II, nilai terendah adalah 67 , sedangkan nilai tertinggi mendapat nilai sempurna yaitu nilai 100 , nilai rata-rata pada siklus I adalah 62,8 , sedangkan nilai rata- 
rata pada siklus 2 adalah 85,9. Hal ini menunjukkan adanya kenaikan yang sangat positif yakni berada di angka selisih 23,1 , dari 9 siswa terdapat b siswa yang telah tuntas KKM dan hanya ada satu siswa yang belum tuntas KKM pada materi sistem peredaran darah manusia.

Berdasarkan refleksi pada siklus II maka diputuskan untuk melanjutkan ke siklus III dikarenakan belum mencapai target yang diharapkan. Pada siklus III penggunaan metode bermain peran menjadi pilihan dengan tetap mengunakan pendekatan saintifik. Berikut ini adalah hasil belajar peserta didik pada siklus III yang bisa dilihat pada tabel berikut.

Tabel 3.Rekapitulasi hasil tes formatif siklus III

\begin{tabular}{|c|c|c|c|c|c|c|}
\hline \multirow{2}{*}{ No } & \multirow{2}{*}{ Nama } & \multirow{2}{*}{ Siklus 2} & \multicolumn{4}{|c|}{ Siklus 3} \\
\hline & & & Nilai & MK & BMK & Ket. \\
\hline 1 & $\begin{array}{l}\text { Ajeng } \\
\text { Zanimar }\end{array}$ & 80 & 87 & $\checkmark$ & & $\mathrm{T}$ \\
\hline 2 & Alisyah Nur F. & 80 & 87 & $\checkmark$ & & $\mathrm{T}$ \\
\hline 3 & Destiana Ts. & 87 & 93 & $\checkmark$ & & $\mathrm{T}$ \\
\hline 4 & Haikal Fadli & 93 & 93 & & $\checkmark$ & $\mathrm{T}$ \\
\hline 5 & Hazwa Kh. & 93 & 100 & $\checkmark$ & & $\mathrm{T}$ \\
\hline 6 & Kais Setiawan & 67 & 80 & $\checkmark$ & & $\mathrm{T}$ \\
\hline 7 & Nabila Aulia & 100 & 100 & $\checkmark$ & & $\mathrm{T}$ \\
\hline 8 & $\begin{array}{l}\text { Nindya } \\
\text { Raudya }\end{array}$ & 93 & 100 & $\checkmark$ & & $\mathrm{T}$ \\
\hline $\begin{array}{c}9 \\
\text { Nilai }\end{array}$ & $\begin{array}{l}\text { Titi Wiji R } \\
\text { rata-rata }\end{array}$ & $\begin{array}{c}80 \\
85,9\end{array}$ & $\begin{array}{c}87 \\
91,8 \\
\end{array}$ & $\checkmark$ & & $\mathrm{T}$ \\
\hline
\end{tabular}

Hasil siklus III adalah sebagai berikut : kenaikan hasil belajar dari pra siklus sampai dengan siklus 3 menunjukkan perkembangan hasil belajar yang positif; terdapat kenaikan rata-rata hasil belajar sebesar 42, 1 (pra siklus 49,8 sedangkan siklus tiga 91,9, terdapat 3 siswa yang mendapat nilai sempurna yakni nilai 100 pada siklus 3, satu diantaranya pada pra siklus hanya mendapat nilai 47; kenaikan hasil belajar siswa dengan rentang tertinggi terdapat antara siklus satu ke siklus 2 yakni dari nilai rata-rata 62,8 ke 85,9 . Hasil penelitian ini juga sesuai dengan penelitian sebelumnya yang dilakukan oleh Yoga Prasetya (2016) yang membuktikan bahwa pendekatan saintifik dalam pembelajaran dapat meningkatkan hasil belajar siswa.

\section{SIMPULAN}

Penerapan pendekatan saintifik dapat meningkatkan hasil belajar siswa pada kompetensi pengetahuan pada muatan pelajaran IImu Pengetahuan Alam dalam materi sistem peredaran darah manusia kelas V Sekolah Dasar Negeri Arjosari. Hal ini ditunjukkan dengan ketuntasan klasikal hasil belajar pada muatan pelajaran IPA pada siklus I sebesar $22 \%$, pada siklus II meningkat sebesar $67 \%$ menjadi $89 \%$ dan pada siklus III meningkat sebesar $11 \%$ menjadi $100 \%$, Dapat dibuat deskripsi yang jelas sesuai dengan dengan kondisi di kelas saat pelaksanaan tindakan tiap siklusnya tentang penerapan pendekatan saintifik dapat meningkatkan hasil belajar siswa pada muatan pelajaran IImu Pengetahuan Alam dalam materi sistem peredaran darah manusia kelas V Sekolah Dasar Negeri Arjosari.

Hasil dari penelitian ini akan ditindaklanjuti kembali dengan meminimalkan periode siklus berupa pengulangan pembelajaran. Selain itu, hasil dari penelitian ini akan diujicobakan lagi pada materi atau mata pelajaran lain dan juga akan diseminasikan dengan teman seprofesi dalam acara KKG. 


\section{DAFTAR PUSTAKA}

Akhmadi, Agus. 2016. Penelitian Tindakan Kelas (Panduan Praktis Pengembangan Profesi Guru dan Kkonselor). Sidoarjo: IKAPI.

Prasetya, Yoga. 2016. "Penerapan Pendekatan Saintifik Untuk Meningkatkan Hasil Belajar Siswa Pada Materi Geometri Kelas X SMA Negeri 2 Kota Bengkulu."Skripsi. Bengkulu :Universitas Bengkulu.

Supriyadi. 2011. Strategi Belajar Mengajar. Yogyakarta : Cakrawala IImu.

Suyono, Hariyanto, 2011. Belajar dan Pembelajaran, Bandung : Pt. Remaja Rosdakarya

Hosnan. 2014. Pendekatan Saintifik dan Kontestual dalam Pembelajaran Abad 21. Bogor: Ghalia Indonesia

Kemendikbud Direktorat Pendididkan Dasar. 2013. Panduan Teknis Penerapan Kurikulum 2013 Jenjang SD: Penilaian Otentik. Jakarta. Kemendikbud Direktorat Pendididkan Dasar.

Berpendidikan.com. (2020, 4 April). Pengertian Pendidikan. Diakses pada tanggal 24 Oktober 2020, dari https://www.berpendidikan.com/2020/04/pengertianpendekatan.html

Kajian Pustaka.com. (2019, 27 Mei) Pengertian, Prinsip, dan Langkah Pendekatan Saintifik. Diakses tanggal 24 Oktober 2020. Dari https://www.kajianpustaka.com/2019/05/pengertian-prinsip-dan-langkahpendekatansaintifik.html\#: :text=Menurut\%20Karar\%20dan\%20Yenice\%20(2012,merumus kan\%20masalah\%2C\%20merumuskan\%20hipotesis\%2C\%20mengumpulkanextid.

Slideshare.net. (2013, 1 Desember). Pengertian Pendekatan, Strategi, Metode, Teknik, Taktik dan Model Pembelajaran. Diakses pada tanggal 24 Oktober 2020, dari https://www.slideshare.net/dediyulianto370/pengertianpendekatan\#: :text=Dalam\%20pengajaran\%2C\%20approach\%20diartikan\%20se bagai,asumsi\%20mengenai\%20cara\%20belajar\%2Dmengajar. 